\title{
BARTOLOMÉ DE LAS CASAS' CULTURAL TURN IN HIS INTERPRETATION OF ARISTOTLE AND THOMAS AQUINAS
}

\author{
O giro cultural de Bartolomé de Las Casas na sua \\ interpretação de Aristóteles e de Tomás de Aquino. \\ El giro cultural de Bartolomé de Las Casas en su \\ interpretación de Aristóteles y Tomás de Aquino
}

Michael Schulz'

Universidade de Bonn, Bonn - Alemanha.

\begin{abstract}
In order to protect the indigenous population of the Americas from slavery and war, Bartolomé de Las Casas (+1566) carries out a cultural turn in the understanding of what is considered "natural". The idea that there are slaves by nature was explained in the colonial period by recourse to Aristotle and in view of the inhabitants of the West Indies. A warlike subjugation of disobedient and rebellious slaves was therefore a "natural" affair - like the entire European expansion. Drawing on Aristotle's understanding of ethos and Aquinas' considerations of human beings' natural knowledge of God, Las Casas initiates a culturalist interpretation of human nature. In this way, the indicators that are supposed to qualify the Indians as homunculi and slaves by nature are re-qualified as indicators of authentic humanity. The article reconstructs Las Casas' innovative cultural argumentation.
\end{abstract}

Keywords: Bartolomé de Las Casas, natural slavery, just war, human nature, culturalist interpretation, cultural argumentation.

\footnotetext{
- PhD and habilitation in Theology (LMU Munich). Director of the Department "Philosophy and Theory of Religions" and of the "Interdisciplinary Latin America Center", Rheinische FriedrichWilhelms-University, Bonn / Germany.https://www.ptr.uni-bonn.de E-mail: michael.schulz@ uni-bonn.de. ORCID: http://orcid.org/o0oo-0002-5410-5962
} 


\section{Resumo}

No intuito de proteger da escravidão e da guerra a população indígena das Americas, Bartolomé de Las Casas (+1566) leva a cabo uma virada cultural no entendimento daquilo que é considerado "natural". A ideia de que existem escravos por natureza foi explicada, no período colonial, por recurso a Aristóteles e com vistas aos habitantes das Índias Ocidentais. Uma sujeição pela guerra de escravos desobedientes e rebeldes era, portanto, um questão "natural" - assim como a expansão europeia por inteiro. Baseando-se no entendimento de ethos de Aristóteles e nas considerações de Tomás de Aquino sobre o conhecimento natural de Deus que os seres humanos possuem, Las Casas inicia uma interpretação culturalista da natureza humana. Dessa maneira, os indicadores que supostamente qualificam os índios como homunculi e escravos por natureza são re-qualificados como indicadores de autenticaa humanidade. $O$ artigo reconstrói a inovadora argumentação cultural de Las Casas.

Palavras-chave: Bartolomé de Las Casas, escravidão natural, guerra justa, natureza humana, interpretação culturalista, argumentação cultural.

\section{Resumen}

Con el fin de proteger de la esclavitud y la guerra a la población indígena de las Américas, Bartolomé de Las Casas (+1566) lleva a cabo un giro cultural en la comprensión de lo que se considerado „natural“. La idea de que hay esclavos por naturaleza se explicó, en el período colonial, por el uso de Aristóteles y con vistas a los habitantes de las Indias Occidentales. Por lo tanto, una sujeción de la guerra de esclavos y rebeldes desobedientes era una cuestión „natural“ - así como toda la expansión europea. Basándose en la comprensión de ethos de Aristoteles y las consideraciones de Tomas de Aquinas sobre el conocimiento natural de Dios que poseen los seres humanos, Las Casas comienza una interpretación culturalista de la naturaleza humana.

Por lo tanto, los indicadores que supuestamente califican a los indios como homunculi y esclavos por naturaleza se recalifican como indicadores de auténtica humanidad. El artículo reconstruye la innovadora argumentación cultural de Las Casas.

Palabras clave: Bartolomé de Las Casas, esclavitud natural, guerra justa, naturaleza humana, interpretación cultural, argumentación cultural. 


\section{Farewell Aristotle?}

Valeat Aristoteles! A Christo enim qui est Veritas aeterna habemus: Diliges proximum tuum sicut teipsum ${ }^{2}$. That says it all. The Dominican Bartolomé de Las Casas (1484/85-1566) bids Aristotle (384-322 BC) farewell - for, Christ has come. He commands charity. Charity cannot be denied to the Indians. The conclusion is obvious: slavery is not compatible with charity. Should Aristotle disagree in this case, Las Casas reminds us that the Greek philosopher was only a heathen and is now burning in the fires of hell.

These drastic words came in a dispute with Juan Cabedo, the first bishop of Tierra Firme, of Santa María del Darién in Panamá3. The debate revolved around the Indians' humanity. With arguments from Aristotle, the bishop questioned the personhood of the Americas' indigenous population. According to Las Casas, the debate took place in 1519. The prominent listener of this dispute in Barcelona was the young emperor, Charles V (1500-1558). Although Aristotle's authority seems to burn with him in the fires of hell, with his knowledge of Aristotle, Las Casas showed that he was ready to stand up to the bishop and to impress the emperor.

The Las Casas specialist Bruno Rech and the church historian Mariano Delgado have their doubts about Las Casas' ability to employ Aristotle so profoundly in his arguments as early as $1519^{4}$. For, it was only three years later that Las Casas joined the Dominican Order and would, thus, have become acquainted with Aristotle's philosophy. During his studies, Las Casas was, as Lewis Hanke puts it in his book Aristotle and the American

\footnotetext{
2 Bartolomé de LAS CASAS: Argumentum Apologiae adversus Genesium Sepulvedam theologum cordubensem [1550], in: Obras Completas, Madrid: Alianza Editorial 1988, vol. 9, ch. 3, fol. 21-22. Eduardo Andújar: "Bartolomé de LAS CASAS and Juan Ginés de SePúlveda: Moral Theology versus Political Philosophy". In Kevin WHITE (ed.): Hispanic Philosophy in the Age of Discovery. Washington D.C.: Catholic University of America Press 1997, pp. 69-87, here p. 77.

3 Bartolomé de LAS CASAS: Werkauswahl Bd. 2: Historische und ethnographische Schriften, ed. Mariano DelGado. Paderborn: Schöningh 1995, pp. 311-318.

4 Bruno ReCH: "Bartolomé de Las Casas und Aristoteles". In Jahrbuch für Geschichte Lateinamerikas 22, no. 1 (1985), pp. 39-68, here pp. 40-41; Mariano DeLGAdo, in LAS CASAS: Werkauswahl Bd. 2, p. 311.
} 
Indians, forced to recognize that Aristotle was the "dominant philosopher in Renaissance times [...] whose ideas had prepared the philosophical substratum of Catholicism" ". Ignoring him was out of the question for Las Casas. In 1550/51, Las Casas demonstrated his knowledge of Aristotle in Valladolid in a dispute with the Aristotle expert Juan Ginés Sepúlveda (1490-1573) who called the Indigenes homunculi. In addition, his works, which he began writing in 1527, five years after joining the Dominican Order, also bear witness to his knowledge of Aristotle. Perhaps the reference to the superiority of Christ and the eschatological fate of the pagan Aristotle contains a reminiscence of Las Casas' one-time argumentative inferiority, when, in 1519, he was not yet able to answer the bishop with recourse to Aristotle and therefore referred to the higher authority of Christ in order to prevent an argumentative defeat. In his mission-theoretical text De unico vocationis modo omnium gentium ad veram religionem, he already referred not only to Christ's commandment to charity ${ }^{6}$, but to Aristotle as well7, in order to justify his claim that love includes wanting good for a human being. Thus, if the Spaniards claim that charity drives them to the West Indies to spread the Gospel, then war and submission are inadequate means of expressing this love. The suffering, death and utter lack of good they bring to the Indians seems instead to speak for their hatred of the natives.

\section{The Natural Knowledge of God in a Contextual Perspective}

Las Casas offers numerous observations and arguments for the fact that war and submission not only contradict love, but also the human nature of the Indians. In the following considerations, I would like to pick

\footnotetext{
5 Lewis Hanke: Aristotle and the American Indians. A Study in Race Prejudice in the Modern World. Chicago: Henry Regnery Company 1959, p. 17.

6 Bartolomé de LAS CASAS: De unico vocationis modo omnium gentium ad veram religionem, ed. Agustín Millares Carlo. México: FCE 1942, cap. VI, §5, pp. 440-447.

7 Aristoteles: Rhetorik. Griechisch / Deutsch, ed. Gernot Krapinger. Stuttgart: Reclam 2018, II 4, 1380b, pp. 168-169.
} 
up on an argumentative strand, which Las Casas developed in recourse to Aristotle and sharpened through considerations of Thomas Aquinas (1225-1274), namely the question of the Indios' natural knowledge of God, understood as an indication of their humanity. In doing so, I rely, above all, on the extensive work of the Catholic church historian Mariano Delgado from the University of Fribourg in Switzerland on Las Casas ${ }^{8}$. I will not discuss whether Las Casas offers an authentic Aristotle interpretation. Bruno Rech, who has, in various contributions, examined Las Casas' historical sources and use of the Old Testament ${ }^{9}$, as well as the presence of Aristotle in his writings, emphasizes that his writings always have one goal: the defense of the Indians. Las Casas does not pursue a purely philological or historical interest neither in Aristotle nor in Thomas Aquinas. It is also well known that many question the historical value of the information contained in Las Casas' historical accounts and see in his tendentious work the great resource on which the anti-Spanish leyenda negra draws. Others see in him the first liberation theologian who turned the Gospel's socio-political dimensions into a program and made use of philosophical expertise ${ }^{10}$. I do not, however, want to decide these questions today either. I will dedicate myself solely to the question of the natural knowledge of God.

By natural knowledge of God, Christian theology understands knowledge of God that can be achieved thanks to the human capacity for

\footnotetext{
8 Mariano Delgado's notes on Las Casas' interpretation of the Indigenes' natural knowledge of God in his edition of Las Casas' Opera: LAS CASAS, Werkauswahl vol. 2, pp. 331-340, 380-381, 388-389, 412-414.

9 Bruno ReCH: Las Casas und das Alte Testament. In Jahrbuch für Geschichte Lateinamerikas 18 no. 1 (1981), pp. $1-30$.

10 Gustavo GutiérRez: Las Casas: In Search of the Poor of Jesus Christ, trans. Robert R. Barr. Maryknoll: Orbis, 1993; Gustavo GuTIÉRREZ: Dios o el oro en las Indias: Siglo XVI. Lima: Instituto Bartolomé de Las Casas, 1989.
} 
knowledge ${ }^{11}$. This capacity for natural knowledge of God constitutes the possibility of a natural or philosophical theology which operates explicitly with the means and methods of philosophical thought. Theology deals with the possibility and scope of natural and philosophical knowledge of God in order to prove that the human being can, of itself, even be the addressee of the revelation that is the object of theology.

But, this theoretical question also played an eminent role in colonial America. The Indians' natural knowledge of God proved they were potential addressees of the proclamation of the Gospel, which in turn presupposed their human nature.

What distinguishes Las Casas' argumentation in particular is its contextual formatting and cultural turn. Las Casas also uses Aristotle to justify his contextual approach. Only through a contextual understanding of the American indigenous population's natural knowledge of God can he defend the humanity of the Indians. His opponents denied the indigenous people's ability to recognize God. They had no understanding of a knowledge of God with a contextual and cultural character.

Even missionary theologians who built on Las Casas no longer reached the level of his contextualistic argumentation. One exception must be mentioned: the Jesuit José de Acosta (1540-1600)12. According to the German Jesuit and pastoral theologian Michael Sievernich ${ }^{13}$, the Dominican

\footnotetext{
1 The Roman Catholic Church has even elevated the possibility of the natural knowledge of God to the status of dogma, since without a natural (or philosophical) knowledge of God, human beings could not be addressed by a revelation of God - the Christian faith would therefore not be possible at all. See the Dogmatic Constitution Dei Filius of First Vatican Council (24 April 1870): "...God, the principle and end of all things, can be known with certainty by the natural light of human reason from created things." (chapter II). (Sancta Mater Ecclesia tenet et docet, Deum, rerum omnium principium et finem, naturali humanae rationis lumine e rebus creatis certo cognosci posse; invisibilia enim ipsius, a creatura mundi, per ea quae facta sunt, intellecta, conspiciuntur [Rom. I.]) http://www.vatican.va/archive/hist_councils/i-vatican-council/ documents/vat-i_const_18700424_dei-filius_la.html

12 See the considerations of Fermín del PINO-Díaz who edited JosÉ DE AcostA's Historia Natural y Moral de las Indias. Madrid: Consejo Superior de Investigaciones Científicas 2008, pp. XXXI-XXXIX.

13 Michael Sievernich: "Missionstheologien ,nach“ Las Casas“. In Bartolomé de Las CASAS: Werkauswahl, vol. 1: Missionstheologische Schriften, ed. Mariano DeLGADo. Paderborn: Schöningh 1994, pp. 59-85.
} 
Tommaso Campanella (1568-1639) came close to Las Casas' argument, because he attests to every human being's orientation towards God and only accepts a peaceful-persuasive method of mission. He relies on a universal dialogue of religions in the tradition of Abaelard (1079-1142), Ramón Llull (1232-1316) and Nicolaus Cusanus (1401-1464).

\section{Political intelligence and priesthood}

The systematic point of departure for the scholastic question regarding the indigenous people's knowledge of God is the first sentence of Aristotle's metaphysics: "By nature, all men long to know. "14. Like the chief theologian of his order, Thomas Aquinas, Las Casas also considers a striving for knowledge of God as part of this striving for knowledge, for beatitude (S.th. I q. 2 a.1 ad 1). In his Apologética historia, which was probably written after his dispute with Juan Ginés Sepúlveda, Las Casas writes: man is naturally inclined and desires to know the truths, mostly to cognize God, which is why Aristotle said in the beginning of his Methaphisica: Omnes homines natura scire desiderant's.

Las Casas quotes this sentence of Aristotle in Chapter 40 of his work, in which he begins to demonstrate that the indigenous people possess three kinds of intelligence that are part of full human being. Aristotle had described different kinds of prudence in his Nicomachean Ethics which Thomas Aquinas systematized: ad prudentiam pertinere eubuliam [a habit whereby we take good counsel], synesim [understanding, insight] et gnomen [good sense] (S.th. II-II q. 48 a. 1 C) ${ }^{16}$. Here, Las Casas follows Aquinas' Aristotle. He writes of monastic prudence, with which one guides oneself, economic intelligence, with which one organizes household and life together with

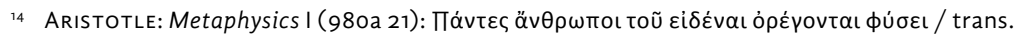
Hugh Lawson-Tancred. London: Pinguin Group, 2004, p. 4.

15 Bartolomé de LAS CASAS: Apologética historia sumaria [1566]. Colombia: Fundación El Libro Total https://www.ellibrototal.com/ltotal/?t=1\&d=4072 $4167 \quad 1 \quad 1 \quad 4072$, cap. XL, p. 534: “...el hombre, naturalmente, es inclinado y desea saber las verdades, mayormente cognoscer a Dios, por lo cual dijo Aristóteles en el principio de su Methaphisica: Omnes homines natura scire desiderant."

16 ARISTOtLE: Nicomachean Ethics VI, 10.
} 
others, and political intelligence, with which one organizes the Polis ${ }^{17}$. As Sepúlveda claims regarding the indigenous people, one gifted with various kinds of prudence (intelligence) can, by nature, be neither slave nor homunculus; but they are "wretched creatures in whom you will hardly find any traces of humanity and who not only do not know any science, but are not even capable of..." This is why they do not have any "written laws, but only some habits of their own and barbaric customs"18. They do not live in a polis. Sepúlveda is also not convinced by the Mexican advanced civilizations and their city states. The lightness with which Cortes defeated the Mexicans proves the deficiency of their human nature ${ }^{19}$.

Therefore, Las Casas spends considerable time discussing political prudence, which presupposes both other kinds of intelligence. Las Casas draws the features that distinguish political intelligence from Aristotle's Politics (VII, 8) about six indispensable tasks and the groups of people assigned to them, without which no autarkic state can be constructed.

17 S.th. II-II q. 48 a. 1, c: "... partes prudentiae, sedundum quod proprie sumutur, sunt prudentia per quam aliquis regit seipsum, et prudentia per quam aliquis regit multitudinem"; this second form of prudence referes to "economy" and "politics"; ad 2: "oeconomica et politica non accipiuntur hic secundum quod sunt scientiae; sed secundum quod sunt prudentiae quaedam." LAS CASAS: Apologética historia sumaria, cap. LX, p. 538: “... una sea prudencia, simpliciter dicha, que dejimos monástica, por la cual el hombre sabe regirse a sí mismo....; La segunda prudencia es la económica, que quiere decir que sabe bien constituir y disponer y ordenar la propia familia o casa para alcanzar el bien común de ella. La tercera es la política, que dispone y ordena rectamente las cosas pertenecientes para conseguir el bien y utilidad común de la ciudad o del reino."

18 Juan Ginés de Sepúlveda: Democrates Secundus / Zweiter Demokrates, ed. and trans. by Christian Schäfer. Stuttgart-Bad Cannstatt: frommann-holzboog, 2018, lib. I, 10, p. 62: “Confer nunc cum horum virorum prudentia, ingenio, magnitudine animi, temperantia, humanitate et religione humunculos illos, in quibus vix reperias humanitatis vestigia, qui non modo nullam habent doctrinam, sed ne litteris quidem utuntur aut noverunt, nulla retinent rerum gestarum monumenta, praeter tenuem quamdam et obscuram nonnullarum rerum memoriam picturis quibusdam consignatam, nullas leges scriptas, sed instituta quaedam et mores barbaros. / Now compare the wisdom of such men, their talent, their spiritual greatness, their temperance, humanity, and fear of God, with those wretched creatures in whom you will hardly find any traces of humanity, and who not only do not know any science, but are not even capable of, or have not even heard of, Scripture; who have no documents of past deeds whatsoever, except for some blurred and dark memories of certain events, vouched for only in paintings, and no written laws, but only some habits of their own and barbaric customs." Christian SCHÄFER: "Juan Ginés De Sepúlveda und die Politische Aristotelesrezeption im Zeitalter der Conquista". In: Vivarium, vol. 40, no. 2, 2002, pp. 242-271, here p. 259.

19 Sepúlveda: Democrates Secundus, lib. I 10, pp. 64-67. 
Proof of the indigenous people's human being would only be possible, if this human goal were attainable in the indigenous societies.

Farmers, craftsmen, warriors, capital providers, priests and judges are the roles that, according to Aristotle, should guarantee the mastery of the six essential tasks of the state. Farmers, for instance, are in charge of securing sustenance for the polis' inhabitants. The defense of the community was the task of the warriors ${ }^{20}$. In his Apologética historia sumaria, Las Casas draws in particular on the institution of priesthood. The priests' task is, perform service to the divine for the good of the polis. The indigenous peoples also have priests and cults.

But according to Sepúlveda, the indigenous peoples fail completely in this regard. He speaks of the impia vero ipsorum religione et nefariis sacrificiis ${ }^{21}$. Their religion was heinous in its polytheism, their sacrificial rituals sacrilegious in their idolatry and ceremonial anthropophagy. Thus, even if indigenous societies could be praised for the institution of priesthood and its accessories, like temples and rituals, this man-eating and extremely blasphemous cult denied the Indios any claim to belonging to the circle of civilized peoples. For the purpose of eliminating blasphemy and ritual perversions, Sepúlveda demands a just war with the goal of subjecting and forcefully proselytizing the Indios.

Most of all, Las Casas had to demonstrate that the indigenous people were not at fault, even if demons led them to idolatry ${ }^{22}$. Were it their fault, one could punish them for it. Las Casas achieves this argumentative goal with a contextualization of the natural knowledge of God and a cultural interpretation of Aristotle and Thomas Aquinas.

\footnotetext{
20 LAS CASAS' summary and application of Aristotle's Politics (VII, 8$)$ to the Indigenes in Apologética: farmers (59-60), craftsmen (61-65), warriors (66-68), prosperous men and wealthy tradesmen (69-70), and priests (71ss) - according to Aristotle's Politics VII, 8: 1328b.

21 Sepúlveda: Democrates Secundus, lib. I 11, p. 66.

22 With the tradition of his time, Las Casas attributes idolatry to the work of the demons: LAS CASAS: Apologética, cap. 74: "...como la rectitud del verdadero culto divino hecho al verdadero Dios, fundado en la lumbre y inclinación natural, es obra y don del Criador y se dice natural, así por el contrario, la perversidad y abusión del hecha reverencia y sacrificio al que no es Dios, que llamamos idolatría, procede y es efecto de la obtenebración, oscuridad, ignorancia y corrupción natural, ayudada y atizada con la malicia e industria demoniaca..."
} 


\section{Ethos and Leopards}

Las Casas tries to prove the plausibility of a contextual perspective, from which the human nature comes into view, by drawing on Aristotle. He cites, among other works, Aristotle's Rhetoric, in which he writes: ö $\mu o \mathrm{ov}$

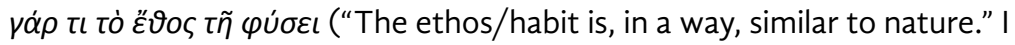
$11-1369 \mathrm{~b}$.) From this similarity of the ethos with nature results a unchangeability of ethos because nature does never change. Frequently throwing a stone into the air, Aristotle explains in his Ethics, does not change its nature ${ }^{23}$. It always falls back down, never upwards. Thus, Las Casas writes, if "consuetudo similis est natura, ideo difficile est ipsam mutare"24. Ethos transports ethical (moral) virtues and structures for understanding and action. The ethos gains in evidence and can become self-evident. From this consideration of Aristotle's, Las Casas concludes that customs and traditions could become so powerful that they produce an "otra naturaleza"25, that is, another (Delgado translates it as a "second"26) human nature. Idolatry that has become part of customary nature cannot simply be done away with.

As an example, Las Casas names the People of Israel, which became accustomed to idolatry during its time in Egypt and for this reason continued to worship false gods in the land of Canaan. The Dominican cites the prophet Jeremiah, who seems to confirm Aristotle's theses about the near impossibility of changing customs: "Can an Ethiopian change his skin or a leopard its spots? Neither can you do good who are accustomed to doing evil." (Jer. 13:25) ${ }^{27}$

\footnotetext{
23 ARIStotle: Nicomachean Ethics II, 11103 a.

24 LAS CASAS: Apologética, cap. 74.

25 LAS CASAS: Apologética, cap. 163: With regard to the idolatry in Israel, which was very difficult to overcome, Las Casas assesses with reference to Aristotle: "Desto era causa la costumbre y en ellos de idolatrar envejecida, la cual suele causar tortísima inclinación, y mueve inclinando como la misma naturaleza, de donde vino a decir Aristóteles ser la costumbre otra naturaleza". ARISTOtLE: On Memory and Reminiscence 2: 452a: "Custom now assumes the role of Nature."

26 LAS CASAS: Werkauswahl Bd. 2, 398, 435: "...die Gewohnheit sei eine zweite Natur...."

27 LAS CASAS: Apologética, cap. 74, 163.
} 
Ultimately, the two decisive faculties, philosophical reason and biblically witnessed faith were in agreement that a given culture can become human nature.

It is obvious that Las Casas turns Aristotle's reflections on ethos and nature in an almost opposite direction. While Aristotle's cultural comparison emphasizes the superiority of life in the polis, Las Casas uses it to emphasize cultural relativity. He even goes so far as to place the Indigenes above the Spanish in terms of their virtuousness or physical beauty. For Aristotle, the Greeks' superiority over barbarians, however cultivated and civilized them may be, is not a matter of debate. While Las Casas does not throw Christianity's superiority into question, he seriously questioned the credibility of the way in which the Christian Faith was to be transported to the Americas.

\section{Naturalness and ideal of human sacrifice}

After drawing on Aristotle to develop a contextual perspective, in which the Indian religion can be understood as a natural phenomenon, he returns to the philosopher in order to identify the inner logic of human sacrifice. He cites the Nicomachean Ethics (VIII, 16 1163b), according to which all those are righteous who try to properly honor the gods according to their abilities ${ }^{28}$. As Las Casas concludes, should human beings come up with the idea of sacrificing what they treasure most, like their own children, one must recognize their political intelligence even in this case. They sacrifice people in order to preserve the common good of the state ${ }^{29}$.

28 LAS CASAS: Apologética, cap. 183. Regarding the honor to be bestowed upon the gods, Aristotle Nicomachean Ethics VIII, 16 (1163b) says that "no one can reimburse for dignity, but if he does so to the best of his ability, he will be considered decent." And the best that humans can do for the honor of the gods is to offer them sacrifices.

29 LAS CASAS: Apologética, cap. 183: “La razón es clara: porque ofrecían a los que estimaban ser dioses la más excelente y más preciosa y más costosa y más amada de todos naturalmente, y más provechosa de las criaturas, mayormente si los que sacrificaban eran hijos; y nuestro entendimiento, como queda dicho, por la lumbre natural juzga que a Dios se le debe ofrecer lo más digno y lo mejor, estando dentro de los límites de la ley natural, faltando ley positiva, humana o divina, que ofrecer hombres prohiba y estorbe..." 
Las Casas adds to this argument the consideration that, because human sacrifice follows a demonstrable inner logic, it is no surprise that the wise members of a people held on to this practice of human sacrifice. Orienting oneself in the community according to the wisest and their judgments, Las Casas argues, once again pointing to the Aristotle's Rhetoric $(I, 11: 1370 a)$, attests to correct behavior ${ }^{30}$. Thus, if the wisest members of a society consider the institution of human sacrifice as one beneficial to the common good, this is not the fault of the people.

Las Casas goes so far as to hold up as a virtue before his fellow countrymen the indigenous people's readiness to sacrifice what is most dear to them for the sake of the common good. With this, he wants to shame the Spaniards. For, in reality, they are the ones who blasphemously sacrifice human beings. They sacrifice the Indigenes in service of their own idol, gold. More people have died for their greed for gold than the indigenous people ever would have sacrificed in their cults.

Naturally, Sepúlveda does not accept this argument on behalf of human sacrifice and accuses Las Casas of abusing Aristotle's authority ${ }^{31}$. The Indios are barbarians and slaves by nature. Las Casas rejects the accusation of distorting Aristotle. He had not drawn upon the philosopher to justify human sacrifice before God, but rather, before human beings in order to prevent a war against the indigenous people ${ }^{32}$. The Indios are definitely barbarians with a different culture and language, but this does not preclude their operating with political intelligence, and they are in no way cultural or moral monsters who could justifiably be hunted.

\footnotetext{
30 LAS CASAS: Apologética, cap. 74.

${ }^{31}$ Sepúlveda's answers, in: Bartolomé de LAS CASAS: Werkauswahl, vol. 1: Missionstheologische Schriften, ed. Mariano Delgado. Paderborn: Schöningh, 1994, pp. 373-389, here 385.

32 LAS CASAS: Werkauswahl, vol. 1: 414-415.
} 


\section{Intercultural Quetzalcóatl}

When defending the Indios, Las Casas does not forget to also look for signs that cultural nature can change, however hard this may be. A change demands, according to Las Casas, a new culture either initiated by particularly wise people or originating in divine revelation. Las Casas claimed he could prove multiple cases of such people with culturally transcendent abilities in the societies of those indigenous to the Americas'. He names gods and cultic heroes in Mexico and Peru who embody virtues, not vices, unlike many of the Greeks and Romans' gods.

In addition, he discovered in Aztec culture a prominent example of cultural change: the Toltekens, Aztecs and Mayans' worship of the deity Quetzalcóatl, also the name of a Toltek king. What matters for Las Casas is that Quetzalcóatl was elected as a god because he "could not hear things of war, nor the sacrifices of men and anything else be in harm of the republic " 33 The deity Quetzalcóatl, who rejected human sacrifice, was Las Casas' proof that the indigenous people could and had once overcome their customary nature - despite all the difficulties. Las Casas' anthopological thesis is the perfectibility of the human being. Humans are open for the new, for Christianity.

In his ethnological-theological study, In the Beginning was the Sacrifice, Gilberto da Silva points out that the Aztec spiritual teachers, the Tlamatinime, found in Quetzalcóatl, a great example for a change. In their philosophical poetry called Flowers and Songs, they lend expression to the replacement of cultic sacrificial gifts by the search for truths that lay claim to the entire human being. The Aztec spiritual teachers consequently inaugurated, as da Silva sees it, a non-violent religion ${ }^{34}$.

\footnotetext{
33 LAS CASAS: Apologética, cap. 127: "no podía oír cosas de guerra, ni los sacrificios de hombres y otra cosa ser en daño de la república."

34 Gilberto DA SILVA: Am Anfang war das Opfer. René Girard aus afroindiolateinamerikanischer Perspektive. Münster-Hamburg-London: Lit, 2001, 139-141.
} 


\section{Las Casas as an intercultural thinker}

To summarize: proceeding from Aristotle, Las Casas attains an understanding both for the unity of human nature and culture as well as for their differences. He is able to think historically-perspectivaly, contextually and interculturally. Something that seems to be something natural and self-evident and can thus take on the character of a law of nature, can be understood completely differently in another culture. Idolatry and human sacrifice are thus seen in many human cultures as natural and self-evident. For this reason, a tremendous amount of energy, including not least of all, the conversion to Christianity, was also necessary for Europe to free itself from idolatry and human sacrifice and take on a new path. When a new path becomes habit, that which was once considered natural now appears perverse and unnatural. As mentioned, according to Las Casas, there are the Spaniards who now give the example of perverse and unnatural behavior. They are the real barbarians. The Spaniard's misuse of Christianity taught Las Casas to differentiate between religion and culture.

Las Casas thinks interculturally. He does not understand cultures as unchanging worlds that only stand in opposition to one another. By pointing to cultural and religious-historical developments, he argues for the inner plurality and plasticity of cultures which can, for this reason, enter into relationships with one another. The Mexicans' or Peruvians' virtuous gods, above all Quetzalcóatl, who strictly rejects human sacrifice, show the indigenous culture's openness for change, for a change that could lead to the end of human sacrifice.

Those who know Europe's religious history, Las Casas concludes, have - thanks to their own history - the hermeneutic key to an understanding of the indigenous, foreign culture and religion. This interaction with the indigenous people should help the Europeans to remember their own former status as barbarians and idolaters. In this recollection of one's own history and its darker periods lies the potential for intercultural understanding. On the other hand, Las Casas does not advocate cultural relativism. Like Aristotle's idea of the polis, it is the veritas aeterna of the 
revelation which provides definitive orientation toward a life in God's polis, in the Civitas Dei and helps to discover truths in other cultures.

\section{Aristotle's efforts}

Now, Las Casas applies the contextual and cultural understanding of human nature to the question of natural knowledge of God. This knowledge of God cannot be anything other than culturally formed, while at the same time remaining open to modification. Las Casas once again calls upon Aristotle, whose Metaphysics presents the demonstration of the unmoved mover's existence. A natural knowledge of God or, in Aristotle's case, a philosophical knowledge of God is possible independent of revelation and Christianity.

Ironically, Las Casas points out that Aristotle only reached knowledge of God after extensive efforts and many books in his physics and metaphysics ${ }^{35}$. Las Casas also cites an unverified anecdote, according to which Aristotle thanked the unmoved mover in a prayer for finally having been found him: "I have found you, the first cause; please, allow that I please you." 36

The Dominican does not further explain how the unmoved mover, which is concerned only with itself and its attractiveness, can be the very first causal cause of the universe, and how it can also have an open ear for the prayers and thoughts of others.

Whatever may be the case, decisive for Las Casas is the energy it cost Aristotle to make it to this philosophical knowledge of God. This is the basis for another important argument: one cannot make something that costs Aristotle great effort the standard for natural knowledge of God. Yet, this is what Las Casas' opponent presume. In his Democrates secundus, Sepúlveda explains that he would spare the indigenous people and in no way threaten them with war, if only they were praying the prayer of Aristotle, so to

\footnotetext{
35 LAS CASAS: Apologética, cap. 71: “...trabajó no poco Aristóteles [...] hasta que llegó a que había un movedor, sin se mover, de todas las cosas."

${ }^{36}$ LAS CASAS: Apologética, cap. 71.
} 
speak, and worship the unmoved mover and the universe's first cause in philosophical faith. Those who have achieved a philosophical monotheism do not celebrate human sacrifice. They are not slaves by nature ${ }^{37}$.

Las Casas has to show that Aristotle's knowledge of God is not normally the case but rather an exceptional one. On the other hand, Las Casas is convinced that a culture that produced someone like Aristotle should also made responsible for not following him in his knowledge. The fact that the Greeks and the Romans, who employed Greek tutors for their education, nonetheless fell victim to polytheism and idolatry, documents their religious failure and proves their barbaric sin. To put it another way, even Aristotle cannot be seen as the religious norm for Greco-Roman culture. How, then, can Sepúlveda declare a philosophical monotheism the standard for indigenous cultures?

\section{Cognitio Dei confusa: o si uno o si muchos sean}

In order to make comprehensible why the indigenous people hadn't adopted a philosophical monotheism, Las Casas points not only to Aristotle's efforts. In addition, he wants to defend their polytheism as a form of natural

37 Sepúlveda: Democrates Secundus, lib. 1, 12, p. 76: Pagani, Leopolde, qui nihil aliud, peius sunt quam pagani, et quibus nihil obiici potest, nisi quod non sunt christiani, quae infidelitas nominatur, nulla causa est, qua iuste possint christianorum armis infestari atque puniri. Ut si qua gens in Orbe Novo reperiretur culta, civilis et humana, non idolorum cultrix, sed quae deum verum duce natura veneraretur, quaeque sine lege ea, „quae legis sunt“, ut verbis utar Pauli, "naturaliter faceret“, nec tamen lege uteretur evangelica, nec haberet fidem Christi, ut hac ratione debeat infidelis nominari. Huiusmodi ergo gentibus istud recentiorum theologorum, quos citasti, decretum videri potest in causa belli suffragari, ut propter nullam infidelitatis culpam iure possint puniendi gratia a christianis principibus illatis armis oppugnari.

If the Gentiles are nothing worse than Gentiles, Leopold, so nothing else can be reproached of them than that they are not Christians, in which case we speak here of unbelief, then there is no reason how they could justly be attacked and punished by the force of arms of the Christians; so that if a civilized, cultured, and educated people were discovered in the New World who would not adhere to idolatry, but worship the true God according to natural insight and "naturally fulfilled", without law, "all that is in accordance with the law," to say it with Paul, although they are neither subject to the law of the New Covenant, nor have faith in Christ, and one would have to call them unbelieving from this point of view, - as far as the peoples of this beat are concerned, then one could probably speak the word of the decision of the newer theologians about the ability to justify a war: that they, innocent of their unbelief, cannot rightly be combated by the Christian rulers for punishment by force of arms." 
knowledge of the Divine. He even goes beyond Aristotle and cites Thomas Aquinas. Thomas Aquinas adopted the opening sentence of Aristotle's Metaphysics, according to which all human beings strive for knowledge by nature, something which, for Aquinas as for Las Casas, includes the knowledge of God. However, as Thomas makes clear at the very beginning of his considerations of divine knowledge in the Summa Theologiae, while all human beings strive for knowledge and happiness, it is remains unclear whether one can already speak of knowledge of God (St.th. I q. 2, a. 1 ad 1). Thomas explains this limitation by recalling that many people see their highest good not in God, but in possession and pleasure. The reason for this must, therefore, lies deeper: Deum esse non est per se notum (S.th. I q. 2 a. 1, obi. 2)

Las Casas takes up these considerations of the limitations of divine knowledge in order to justify the indigenous people's limited knowledge of God, that is, to depict it as something very human and natural. Thus, Las Casas does not draw primarily on the impossibility, emphasized by Thomas and tradition, of adequately grasping God's essence; he does not reconstruct Thomas' negative theology in the tradition of Dionysius Areopagita. This negative theology presupposes, namely, an already precise, philosophical knowledge of God that has already clearly grasped the transcendence of the one and only God. But, Las Casas does pick up on Thomas' considerations regarding the general difficulties posed by knowledge of God which make themselves noticeable due, for example, to lacking education or time-consuming engagement with profane things (S.c.G I, 4). Left up to its own mean, reason does not necessarily arrive at a certain knowledge of God, not even, if one already knows that possession and pleasure do not constitute the highest human goods.

Las Casas cites a corresponding passage from the Summa contra Gentiles (III, 38) in which Thomas explains that the human being can arrive at a knowledge of God by making natural use of its reason (naturali ratione): in aliqualem Dei cognitionem pervenire potest. Thomas does not, however, specify the character of this divine knowledge. He speaks of a 
confusa Dei cognitio ${ }^{38}$. The occasion for this "particular, general and unclear knowledge of God" (quaedam communis et confusa Dei cognitio) is the order of natural things. Since there is no ordinatio without an ordinator, Thomas argues, an ordinator can be deduced. Decisive for Las Casas is, however, what Thomas says about the definition of this unclear knowledge of God. Thomas writers: Who the world-orderer is and how its nature is structured as well as whether there is only one - quis autem, vel qualis, vel si unus tantum est ordinator naturae - cannot immediately be apprehended through general observation of the world's nature. Las Casas clarifies Thomas' formulation vel si unus tantum by adding "o si uno o si muchos sean los que ordenan las cosas naturales" (or if one or if many are the ones who order the natural things) ${ }^{39}$. Whether the orderer of natural things is one or many cannot be decided with this general, unclear knowledge of God. While Thomas speaks of an ordinator in the singular, Las Casas uses the plural form: los que ordenan. That which Thomas seems to imply, Las Casas makes express: in the context of unclear knowledge of God, it was even possible to assume that the world-orderer be polytheistic in nature.

With his interpretation of Thomas, Las Casas was able to bring his order's star theologian onto his side. In his theological Summa, Thomas illustrated the initial, unclear knowledge of God with an example that Las Casas picks up on. Thomas says that seeing someone coming from afar is not yet the knowledge that it is Petrus coming, as is also the case. It is the same, when one initially recognizes God only from afar. For Las Casas, this means that it cannot be immediately decided whether the ordinator naturae is to be understood polytheistically or monotheistically. To sti-

38 Sascha Salatowsky: De Anima. Die Rezeption der aristotelischen Psychologie im 16. und 17. Jahrhundert. Amsterdam-Philadelphia: B.R. Grüner, 2006. Vgl. Phys. I 1, 184a21-23: „Uns ist aber vor allem deutlich und durchsichtig das mehr Vermengte. Später erst werden aus diesem bekannt die Grundbausteine und die Prinzipien, wenn man es auseinandernimmt." Wie Aristoteles ausführt, so bewegt sich auch Thomas von Aquin zufolge das Erkennen vom

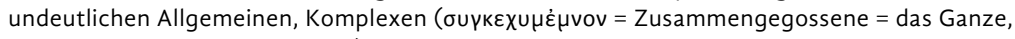
to holon = Mensch gegen Kallias) zur Erkenntnis des Konkreten.

39 LAS CASAS: Apologética, cap. 71. 
ck to the image of a person in the distance: I do not immediately know, whether there is only one person coming to me or a group of persons.

To further prove this thesis, Las Casas cites Marcus Tullius Cicero's (106-43 BC) treatise De natura deorum II, $12 \mathrm{f}^{40}$. The Dominican shares Cicero's ethnological proof of God's existence: gods are worshiped by all peoples of the earth, and that makes evident that gods exist. Las Casas concludes that no one denies the existence of god, but then he adds: "Yet, the philosophers have diverse and different and differing ideas about which and how many gods there are." ${ }^{41}$

With this remark, Las Casas yet again makes clear just how much of an exception Aristotle's philosophical monotheism really is. Philosophical monotheism can never be elevated to the criterion of whether political intelligence correctly organizes the public cult for the common good in a community.

\section{Paul writes to Aristotle of the Greeks and Romans}

In the framework of his contextualist and cultural reading of Aristotle and Thomas, Las Casas also interprets the apostle to the Gentiles Paul. In the first chapters of his letter to the Christian community in Rome, Paul argues that all people are sinners and that, for this reason, all people need a savior without exception: Jesus Christ. Paul's thought moves within a universalist and general-human horizon ( $R m$ 3,23-24).

Las Casas permits himself to change that. In order to prove that not only the Jews are sinners, because the infringed upon Mosaic law, but the pagans as well, Paul takes recourse to the anthropoi, homines $(\operatorname{Rm~1,18)}$ and their nous, with which they are capable of recognizing God and moral

\footnotetext{
40 Las CaSAS: Apologética, cap. 72.

41 LAS CASAS: Apologética, cap. 72. After a detailed philosophical and religious-scientific overview of the different ideas of the nature of the divine, Las Casas comes to the conclusion: "Es verdad luego que todos los hombres del mundo, por bárbaros, incultos y silvestres y apartados en tierras o en islas y rincones del mundo que sean, naturalmente por la lumbre de la razón y del entendimiento agente, con un cognoscimiento confuso y universal, no claro ni distincto, sin tener lumbre de fe cognoscen que hay Dios."
} 
law. In the tradition of Old-Testament wisdom literature, Paul claims that

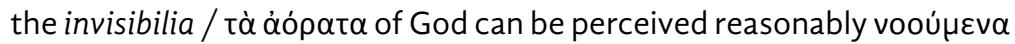

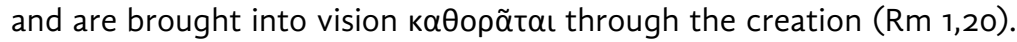
But, in spite of this clear knowledge of God, human beings did not do honor to God. Instead of worshiping the invisible God, they worshiped images of people and animals, that is, gods, Paul notes. For this reason, he comes to the decisive conclusion that human beings are ávamoגopńtous, inexcusabiles $(\mathrm{Rm} \mathrm{1,20})$. They are sinners, in need of redemption.

Conversely, Las Casas must now prove that the Indigenes are indeed excusable. He is only successful in doing so by grasping the anthropoi culturally. Las Casas claims that when Paul wrote ${ }^{42}$, that all humans can perceive the one, invisible God with their reason, he was thinking of the philosophers and the philosophically educated Greeks and Romans. Because they did not follow this knowledge of God and remained polytheists, they are, indeed, inexcusable. But, the indigenous people are excusable because their culture did not pass on to them monotheism's philosophical intellectual legacy. Las Casas does not want to suggest that the indigenous people not be in need of a redeemer. They need a redeemer in order to be free from the power of demonic temptation and to move from an idolatry - that has become customary nature - to the ethos of a new human being. But, this redeemer is neither a just war nor the Spanish.

\footnotetext{
42 Bartolomé de LAS CASAS: Apología, ed. Ángel LoSADA. Madrid: Editora Nacional 1975, 85v-86: "En cuanto a la autoridad de San Pablo, es de señalar que habla de los filósofos que, teniendo el conocimiento de Dios, no lo utilizaron para el bien, sino que se hicieron necios. Dichos filósofos supieron que Dios era un ser excelso por encima de todas las cosas; de esta manera debían tributarle el honor y la gloria... ahora bien, habiendo conocido así a Dios no le glorificaron como Dios... Es cierto que lo anterior no debe aplicarse a todos los comunes mortales; por eso a éstos no se refiere el Apóstol. / As for the authority of St. Paul, it should be noted that he speaks of the philosophers who, having the knowledge of God, did not use it for good, but became fools. Such philosophers knew that God was a supernal being above all things; thus they were to give him honor and glory... now, having thus known God, they did not glorify him as God... It is true that the foregoing should not apply to all common mortals; therefore these are not referred to by the Apostle."
} 


\section{Aristotle - defensor de los Indios}

According to Las Casas, only the arduous work of convincing the indigenous can open up a way to faith in the savior, as he explains in his treatise De unico vocationis modo omnium gentium ad veram religionem. Here too, Aristotle serves him as an authority who proves that reason-endowed creation must always be moved to true religion by "the conviction of reason through reasonable arguments" (intellectus rationibus persuavius), never through violence (no compelle intrare), but through "the gentle lure/attraction and encouragement of the will" (voluntatis suaviter allectivus vel exhortativus) ${ }^{43}$.

Even if Aristotle himself is roasting in hell and Christians receive their Veritas aeterna from Christ - never did Las Casas bid Aristotle farewell. Rather, he managed the hermeneutic feat of making the philosopher into a defensor de los Indios.

\section{Michael Schulz, Rheinische Friedrich-Wilhelms-Universität, Bonn}

Friedrich-Wilhelms-Universität, Bonn

Arbeitsbereich Philosophie und Theorie der Religionen

Raum 3.080

Am Hof 1

53113 Bonn

43 LAS CASAS: De único vocationis modo, cap. 5, § 1, p. 7; references to Aristotle in $\S 2$, p. 14. Crucial is the Thomistic axiom: "Totius ... libertatis radix est in ratione constituta." ( $\$ 3$, p. 30). 


\section{Bibliography}

Andújar, E. Bartolomé de Las Casas and Juan Ginés de Sepúlveda: Moral Theology versus Political Philosophy. In: WHITE, K. (ed.). Hispanic Philosophy in the Age of Discovery. Washington D.C.: Catholic University of America Press, 1997. p. 69-87. https://doi.org/10.2307/j.ctv17609.8

ARISTOTELES. Rhetorik. Griechisch / Deutsch, ed. Gernot KRAPINGER. Stuttgart: Reclam, 2018.

Aristotle. Metaphysics, trans. and ed. Hugh Lawson-Tancred. London: Pinguin Group, 2004.

Aristotle. Nicomachean Ethics, trans. and ed. BARTLETT, R. C. / COLLINS, S.D. Chicago: University of Chicago Press, 2012.

ARISTOTLE. On Memory and Reminiscence, trans. Beare, J. I. Adelaide: University of Adelaide, 2015.

Aristotle. Physics, trans. Reeve, C. D. C. Cambridge: Hackett Publishing, 2018 Aristotle. Politics, trans. Barker, E. Oxford: Oxford University Press, 2009.

DA Silva, G. Am Anfang war das Opfer. René Girard aus afroindiolateinamerikanischer Perspektive. Münster-Hamburg-London: Lit, 2001.

DELGADO, M. Introductions. In: Bartolomé de LAS CASAS. Werkauswahl, vol. 2: Historische und ethnographische Schriften, ed. DELGADO, M. Paderborn: Schöningh, 1995. p. 311, 331-340, 380-381, 388-389, 412-414.

Gutiérrez, G. Dios o el oro en las Indias: Siglo XVI. Lima: Instituto Bartolomé de Las Casas, 1989.

Gutiérrez, G. Las Casas: In Search of the Poor of Jesus Christ, trans. Robert R. Barr. Maryknoll: Orbis, 1993. https://doi.org/10.1086/ahr/100.2.617

HANKE, L. Aristotle and the American Indians. A Study in Race Prejudice in the Modern World. Chicago: Henry Regnery Company 1959.

LAS CASAS, B. de. Apología, ed. Ángel LosadA. Madrid: Editora Nacional, 1975.

LAS CASAS, B., de. Apologética historia sumaria [1566]. Colombia: Fundación El Libro Total https://www.ellibrototal.com/Itotal/?t=1\&d=4072 4167114072.

LAS CASAS, B. de. De unico vocationis modo omnium gentium ad veram religionem, ed. Millares Carlo, A. México: FCE, 1942. 
LAS CASAS, B., DE. Argumentum Apologiae adversus Genesium Sepulvedam theologum cordubensem. In: Obras Completas, vol. 9, Madrid: Alianza Editorial, 1988.

LAS CASAS, B., de. Werkauswahl, vol. 1: Missionstheologische Schriften. ed. DELGADO, M. Paderborn: Schöningh 1994.

LAS CASAS, B., de. Werkauswahl, vol. 2: Historische und ethnographische Schriften, ed. Delgado, M. Paderborn: Schöningh, 1995.

Pino-Díaz, F. “Estudio introductivo”. In: Josef de Acosta. Historia Natural y Moral de las Indias. Madrid: Consejo Superior de Investigaciones Científicas 2008, p. XVII-LVI.

RECH, B. Bartolomé de Las Casas und Aristoteles. Jahrbuch für Geschichte Lateinamerikas, [S. l.], v. 22, p. 39-68, 1985. https://doi.org/10.7767/ jbla.1985.22.1.39

RECH, B. "Las Casas und das Alte Testament". In: Jahrbuch für Geschichte Lateinamerikas, [S. l.], v. 18 p. 1-30, 1981. https://doi.org/10.7788/jbla-1981-0104 Salatowsky, S. De Anima. Die Rezeption der aristotelischen Psychologie im 16. und 17. Jahrhundert. Amsterdam-Philadelphia: B.R. Grüner, 2006. https:// doi.org/10.1075/bsp.43

SCHÄFER, C. "Juan Ginés De Sepúlveda und die Politische Aristotelesrezeption im Zeitalter der Conquista". In: Vivarium, 40 (2002), p. 242-271. https://doi. org/10.1163/156853402320901830

SepúlvedA, J. G., DE. Democrates Secundus / Zweiter Demokrates, trans. and ed. by Christian Schäfer. Stuttgart-Bad Cannstatt: frommann-holzboog, 2018.

SepúlvedA, J.G., DE. „Antworten von Juan Ginés de Sepúlveda“. In: Bartolomé de LAS CASAS: Werkauswahl, vol. 1: Missionstheologische Schriften, ed. DeLGADO. M. Paderborn: Schöningh, 1994, p. 373-389. https://doi.org/10.2307/j.ctv1760q.8

SiEVERNICH, M. "Missionstheologien ,nach' Las Casas". In Bartolomé de LAS CASAs: Werkauswahl, vol. 1: Missionstheologische Schriften, ed. DeLGADo, M. Paderborn: Schöningh 1994, p. 59-85. 